\title{
FABRIC ANALYSIS OF A CORE FROM THE MEIGHEN ICE CAP, NORTHWEST TERRITORIES, CANADA
}

\author{
By R. M. KoERner \\ (Institute of Polar Studies, Ohio State University, Columbus, Ohio 432 ro, U.S.A.)
}

\begin{abstract}
Amstract. Ice samples from a $121 \mathrm{~m}$ core, representing the total thickness of the Meighen Ice Cap near its highest point, were studied for ice fabric, firn- and dirt-layer distribution. The absence of a strongly preferred fabric between the surface and the base of the ice cap at the core site suggests an absence of past or present ice movement at this point. From the variations of ice texture, firn- and dirt-layer distribution with depth it is concluded that the ice cap post-dates the climatic optimum and has never been much thicker than it is at present. There is a possible relic ablation surface at a depth of $50 \mathrm{~m}$ which is estimated to be at least 500-600 years old.
\end{abstract}

RÉsumé. Analyse de fabrique d'une carotte de la Meighen Ice Cap, Territoires du Nord-Ouest, Canada. On a examiné les orientations préférentielles des cristaux de glace et la distribution des couches de névé et de poussière d'une carotte de $121 \mathrm{~m}$ de longueur, extraite à proximité du sommet de la Meighen Ice Cap et représentant donc l'épaisseur complète de celle-ci. L'absence d'orientations préférentielles marquées des cristaux de glace entre la surface et le fond de la calotte indique qu'elle fut jusqu'a présent sans mouvement à la station de carottage. Comme semblent l'indiquer les variations de la texture de la glace et de la distribution des couches de névé et de poussière avec la profondeur, l'origine de cette calotte glaciaire remonte à la période posthypsithermal et son épaisseur n'a jamais été beaucoup plus forte dans le passé. A $50 \mathrm{~m}$ de profondeur se trouve les vestiges de ce que nous croyons être une surface d'ablation datant d'au moins 500 ou 600 ans.

Zusammenfassung. Strukturanalyse eines Bohrkerns des Meighen Ice Cap, Northwest Territories, Kanada. Eisproben eines $121 \mathrm{~m}$ langen Bohrkerns, der die Gesamtdicke des Meighen Ice Cap nahe an dessen höchster Erhebung umfasst, wurden auf ihre Struktur sowie auf die Verteilung von Firn- und Schmelzschichten untersucht. Das Fehlen einer vorherrschenden Struktur zwischen Oberfläche und Untergrund des Eisschildes im Bohrloch lässt darauf schliessen, dass an dieser Stelle weder früher Bewegungen stattfanden noch derzeit stattfinden. Aus der Variation des Eisgefüges und der Verteilung der Firn- und Schmutzschichten mit der Tiefe wird geschlossen, dass der Eisschild auf dem Stand des Klima-Optimums geblieben ist und dass er seine derzeitige Mächtigkeit niemals beträchtlich überschritten hat. Eine Fläche in $50 \mathrm{~m}$ Tiefe, deren Alter auf mindestens $500-600$ Jahre geschätzt wird, ist möglicherweise ein früherer Ablationshorizont.

\section{INTRODUCTION}

Meighen Island lies in the northern part of the Canadian Archipelago (Fig. 1) and since I959 its ice cap has been the centre of glaciological research by the Polar Continental Shelf Project (PCSP) of the Canadian Department of Energy, Mines and Resources. The ice cap is approximately oval in outline, measures $85 \mathrm{~km}^{2}$ and covers about ro per cent of the island (Arnold, 1965). In 1965 PCSP personnel, using a CRREL thermal-coring drill, drilled through the ice cap close to its highest elevation of $268 \mathrm{~m}$ and reached bedrock at a depth of I $21.2 \mathrm{~m}$. Core recovery was complete and the cores consisted of ice except for occasional distinct firn layers down to a depth of $22 \mathrm{~m}$. The author studied the cores on site in May and June r 966 .

\section{Methods}

For the first part of the study, samples were taken from depths of $1,30,62,76,103$ and $120 \mathrm{~m}$. Each sample was cut horizontally from the core and melted to a thickness of $\mathrm{I} \mathrm{mm}$ on a warmed metal plate. It was then placed in a Rigsby stage and the $c$-axis orientation of more than roo crystals measured.

For the second part of the study, samples representing a total length of $40 \mathrm{~m}$ (30 per cent of the core) were taken from evenly spaced intervals throughout the entire core and sectioned vertically, using a hand saw. Each section was melted to a thickness of about $5 \mathrm{~mm}$ and photographed in transmitted light to record the bubble structure. Then, the section was melted to a thickness of $\mathrm{I} \mathrm{mm}$ and photographed in polarized light to record its crystal structure. A few close-up photographs $\left(x_{3}\right)$ were taken of internal melt figures, bubble structures and dirt inclusions. 


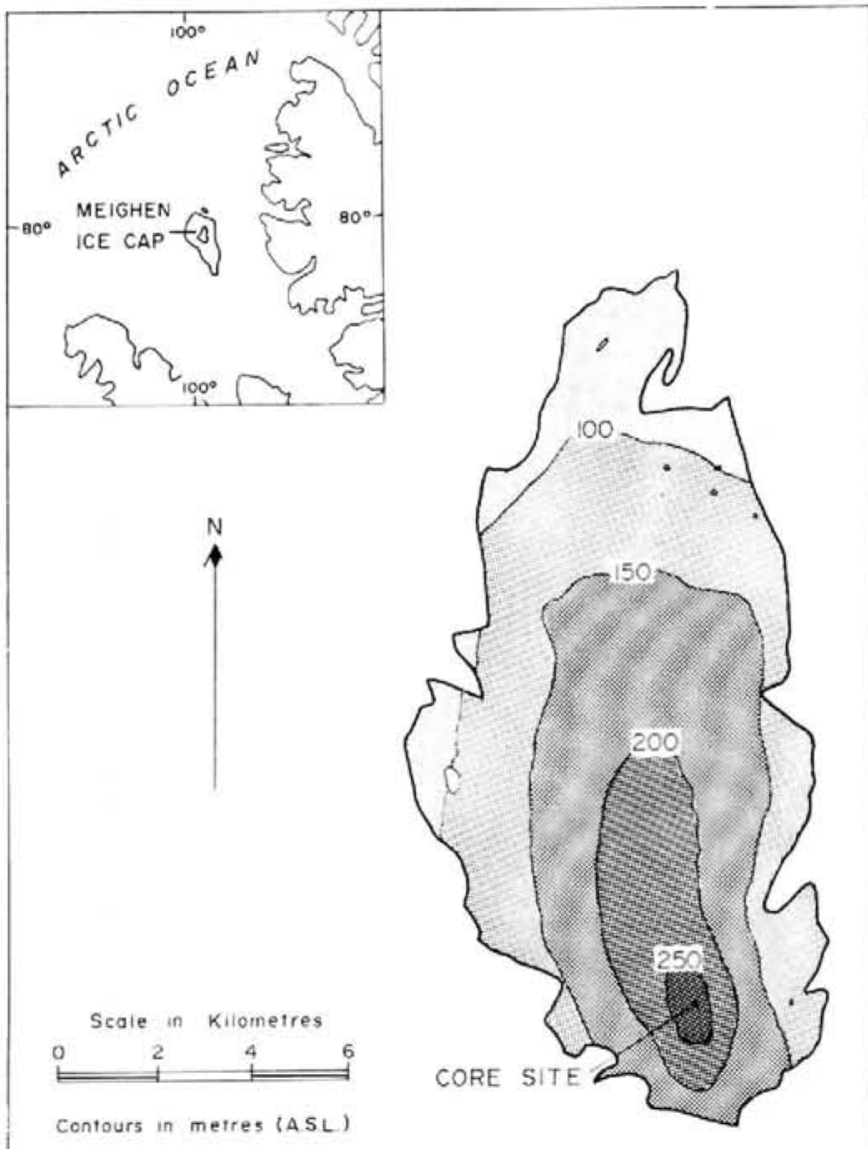

Fig. I. The Meighen Ice Cap.

Results

Crystallographic c-axis orientation

$c$-axes have been plotted and contoured on the lower hemisphere of a Schmidt net. The results are summarized in Table I. Only one sample from the core, at $76 \mathrm{~m}$ depth, showed a preferred orientation with a concentration of $c$-axes greater than 7.5 per cent per I per cent of area. Remaining samples showed weak maximum concentrations, ranging between 5.0 and

Table I. $c$-axis Orientation in Six Samples from the Meighen Ice Cap Core

$\begin{array}{ccc}\text { Depth of sample } & \begin{array}{c}\text { Nimber of } \\ \text { c-axes measured }\end{array} & \begin{array}{c}\text { Maximum concentration, } \\ \text { per cent in I per cent of area* }\end{array} \\ 0.8 & 211 & 5.2 \\ 30.5 & 137 & 5.1 \\ 62.0 & 212 & 7.5 \\ 76.0 & 211 & 11.0 \\ 103.6 & 212 & 6.0 \\ 120.0 & 300 & 5.0\end{array}$
maximum concentration

Normal to surface Normal to surface $5^{\circ}$ from normal to surface Normal to surface $10^{\circ}$ from normal to surface Normal to surface

* As plotted on the lower hemisphere of a Schmidt net. 
7.5 per cent per I per cent of area. The pole of concentration is centred close to the vertical. The ice sample taken within $2 \mathrm{~m}$ of the ice-rock contact showed a maximum of only 5.0 per cent per 1 per cent of area.

\section{Crystal and bubble fabric}

Ice crystals in the core are generally equigranular (Fig. 2a) and there is no evidence of interlocking patterns which are common in strained glacier ice. There is a wide variation of crystal size from layer to layer so that layering in the ice is often very marked. Crystal sizes (expressed here as cross-sectional area) range from 0.01 to $21.0 \mathrm{~cm}^{2}$.

The mean crystal size of each layer has been determined by counting the number of crystals falling within a certain area of a centimetre grid. Crystals falling across the boundary lines of the measuring area were included only if more than half their area was within the counting grid area. The mean crystal size $(\bar{x})$ for the samples from each $10 \mathrm{~m}$ depth interval has been calculated according to:

$$
\bar{x}=\Sigma x_{\mathrm{r}} / n
$$

where $x_{\mathrm{t}}$ is the mean crystal size for each layer in $\mathrm{cm}^{2}$ and $n$ is the number of layers. The results are plotted in Figure 3 .

A variance analysis of the $10 \mathrm{~m}$ means of crystal size has also been made. The trend of increasing crystal size between the surface and $55 \mathrm{~m}$, and the decrease of crystal size towards the base of the core are both statistically significant (at the I per cent level). However, the variations between 55 and $\mathrm{II} 5 \mathrm{~m}$ are not significant and the discussion will consider this interval as consisting of generally coarse ice.

The air-bubble fabric varies in detail from layer to layer. There are many elongate bubbles with the long axis of the bubble normal to the surface, but there are always other spherical bubbles in the same section. No evidence is found in the sampled part of the core of bubble stretching, i.e. where all the bubbles in a single section are elongated with their long axes parallel to each o'her. In general, coarse ice is very clear, whereas fine ice is bubbly, but the study of the relationship between bubble and crystal fabric has not been pursued.

Stratification is evident in the ice core but it is difficult to interpret. Wherever layers are distinct on the photographs (e.g. Fig. 2c) their thickness has been measured. The mode of layer thickness so observed is $9^{-12} \mathrm{~cm}$ and the mean thickness is $12.6 \mathrm{~cm}$. Present-day total accumulation of snow would form an ice layer $15^{-18} \mathrm{~cm}$ thick (Paterson, unpublished). As some run-off usually takes place in a superimposed-ice zone, the mean measured layer thickness of $12.6 \mathrm{~cm}$ of ice may be accepted as a reasonable estimate of mean annual accumulation in the past. However, as there must also have been some years when the balance was negative, this accumulation rate should be considered a maximum.

\section{Firn layers}

The position of dirt and firn layers in the core was recorded by Paterson (personal communication) on extraction of the core. Firn layers occur to a depth of $22 \mathrm{~m}$. Below this no permeable layers occur, but there are occasional very bubbly layers which probably represent old firn (Fig. 2d). Benson (r962) has estimated that the firn-ice transition zone is more than $77 \mathrm{~m}$ deep in dry snow, 6o-75 $\mathrm{m}$ deep in the percolation facies and $\mathrm{o}-35 \mathrm{~m}$ deep in the soaked facies. Some support of buried firn layers may be effected by ice glands crossing that firn layer, but firn is unlikely to occur below $35 \mathrm{~m}$ in a dominantly superimposed-ice zone where the mean density, and hence load, is high. $35 \mathrm{~m}$ is therefore an absolute maximum depth for firn to occur on the Meighen Ice Cap. As the balance is generally negative at the core site now (Arnold, 1965; personal communication from W. S. B. Paterson), it implies that not more than $13 \mathrm{~m}$ of ice have ablated from the surface since the deepest firn layer, now at a depth of $22 \mathrm{~m}$, was at a depth of $35 \mathrm{~m}$. 


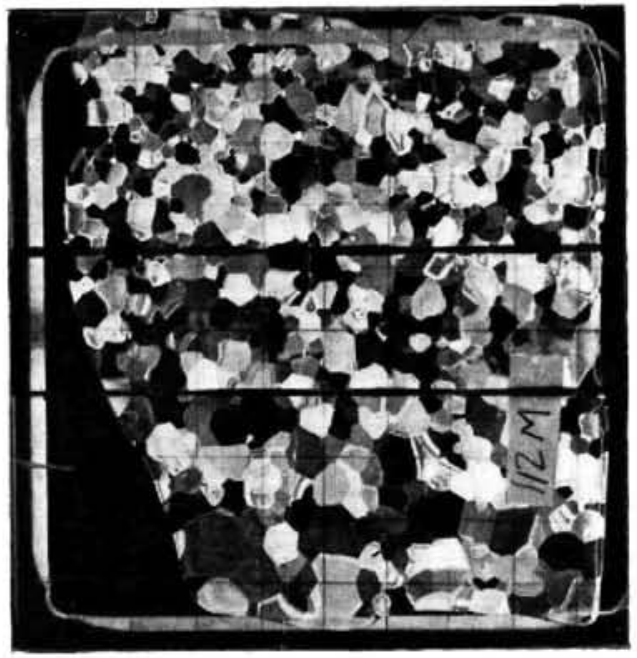

a

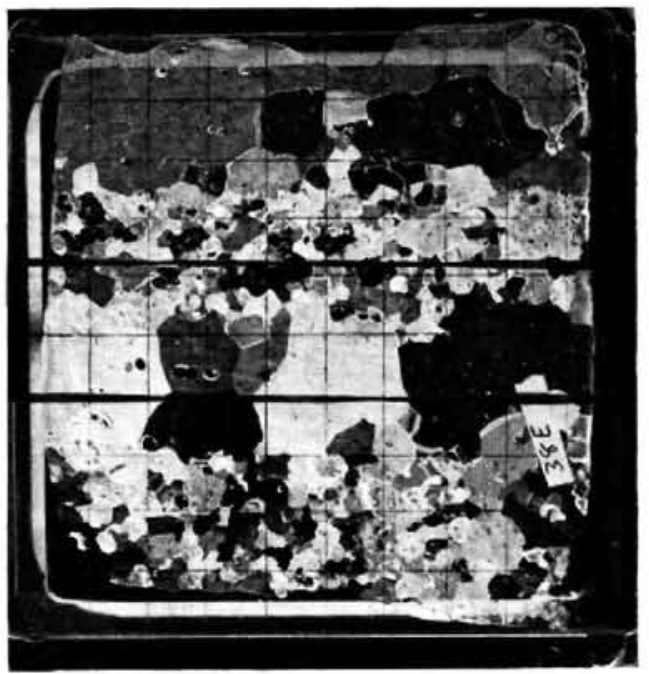

c

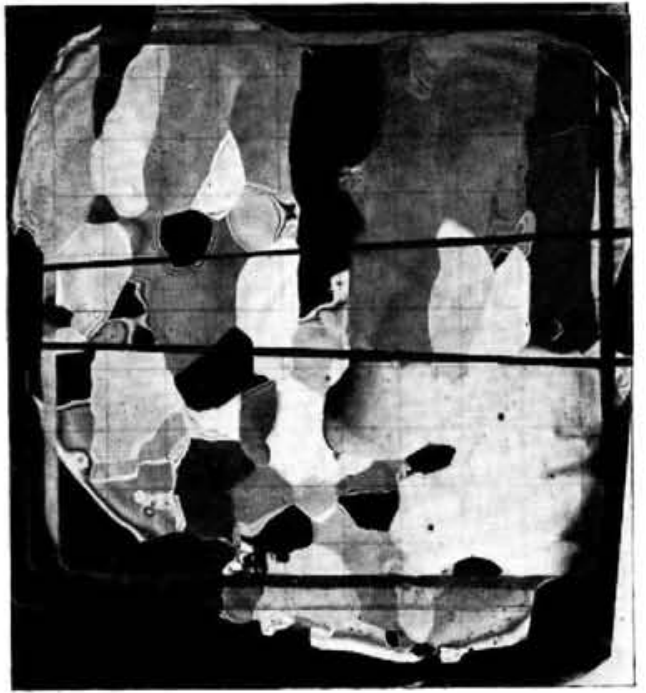

b

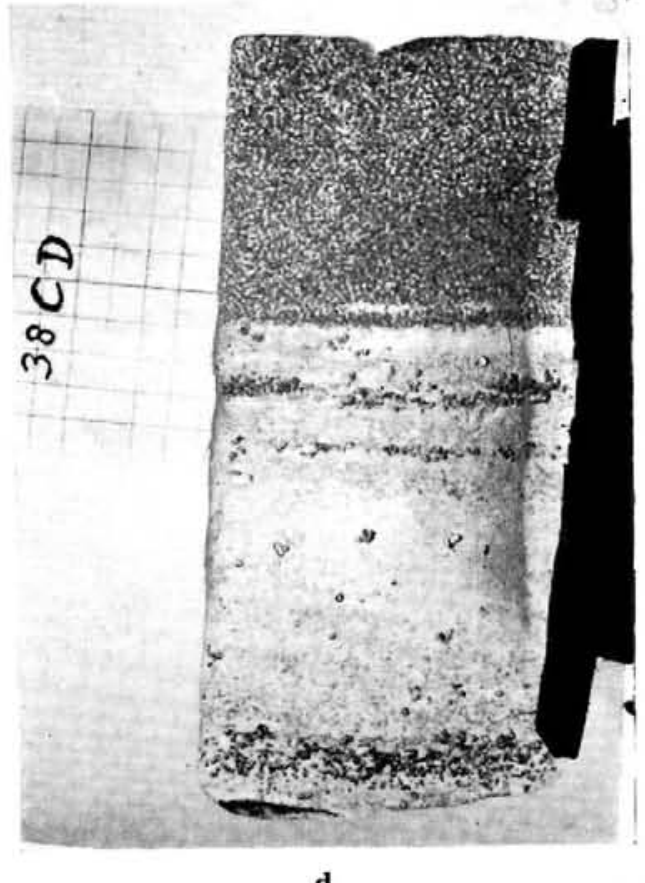

d

Fig. 2. Ice samples from the Meighen Ice Cap core.

The lines across the photographs are rubber bands used to hold the sample in place. All the samples are orientated vertically and shown against a cenlimetre grid.

a. Basal ice from $I 2 I . I-I 2 I .2 \mathrm{~m}$.

b. Moderately coarse ice from $78.7 \mathrm{~m}$. The upper $4-5 \mathrm{~cm}$ of the section consists of pond ice.

c. Ice layering at $40.3 \mathrm{~m}$.

d. Bubbly layer, i.e. old firm, at $40.4 \mathrm{~m}$. 
CRYSTAL CROSS-SECTION AREA $\left(\mathrm{cm}^{2}\right)$

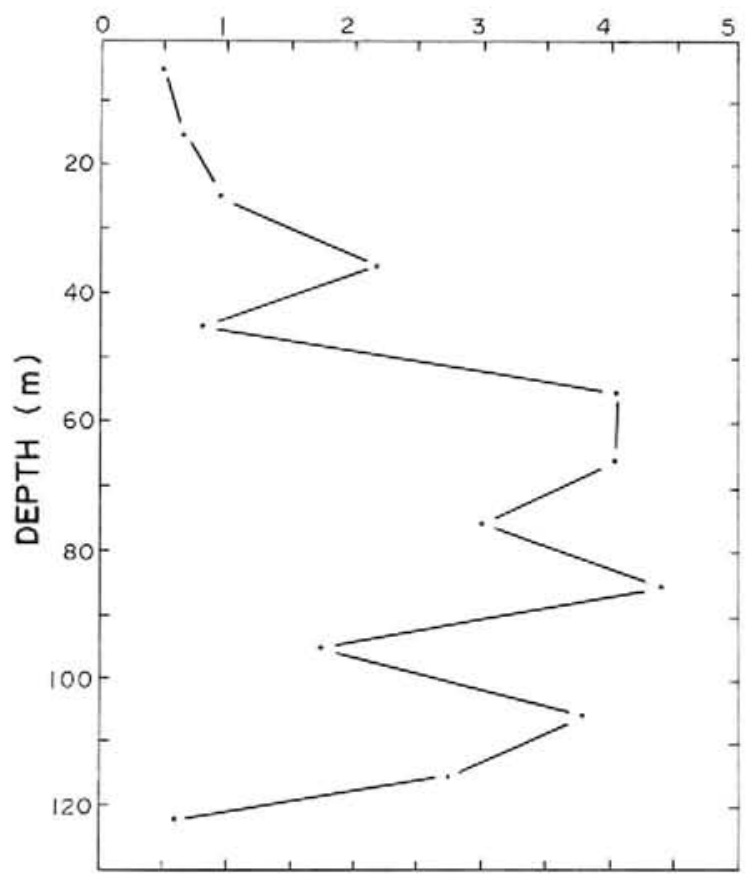

Fig. 3. Variation of ice-crystal size with depth.

\section{Dirt layers}

At many levels in the core there are several $\mathrm{I}-5 \mathrm{~mm}$ pockets of dirt giving the appearance of dirt layers (Fig. 4). The number of dirt layers occurring in each $10 \mathrm{~m}$ is shown in Figure 5 . The dirt particles are generally more than $0.1 \mathrm{~mm}$ in diameter and have been blown on to the ice cap in summer from the surrounding ice-free land. The variation of dirt content with depth is largely a reflection of the variation of the area of ice-free land on the island.

\section{Discussion}

Work by such investigators as Schytt (1958), Langway (1962) and Gow (1963) has shown that depositional ice fabrics have either a random orientation of $c$-axes or a weak preferred orientation; generally less than 6 per cent of the $c$-axes fall within any 1 per cent of an equalarea stereographic plot. Bubble stretching does not occur and the crystals do not interlock. Koerner (unpublished) found that superimposed ice has a depositional fabric very similar to that of firn and ice formed from firn. The crystals of superimposed ice, however, are more nearly equidimensional and may be an order of magnitude larger than those of firn-ice. In the Meighen Ice Cap core, the ice, with the possible exception of that from $76 \mathrm{~m}$ (Table $\mathrm{I}$ ), shows the characteristics of a depositional ice fabric. Furthermore, the fabric indicates that more than 90 per cent of the ice studied is superimposed ice and the remainder is firn-ice. The continuation of the same depositional fabric right to the ice-rock contact indicates that strain-rates in the basal ice layers at the core site have always been very low. This would strongly suggest that there has never been ice movement in the past as it is unlikely that recrystallization in the basal ice could reproduce a random ice fabric from one showing a significant preferred orientation. A survey of surface markers has shown that the ice cap is stagnant today (Arnold, r 965 ). 


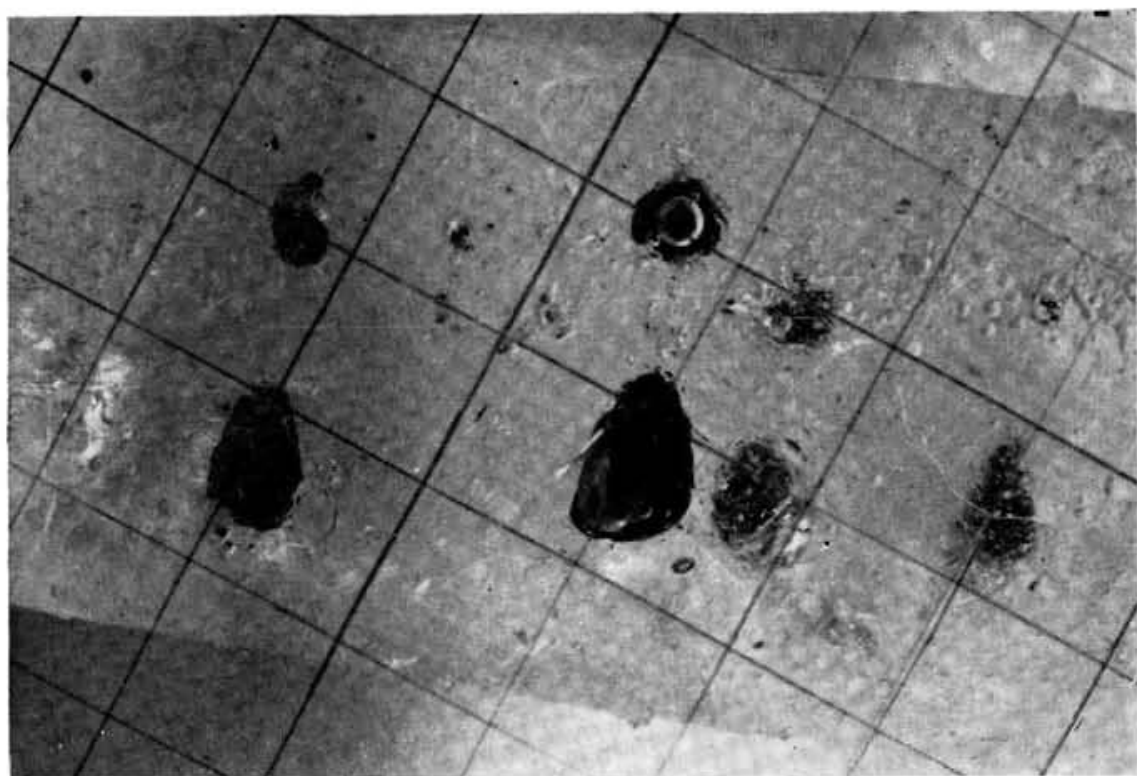

Fig. 4. Close-up of dirt layer, centimetre grid, $100.6 \mathrm{~m}$ depth. The arrow points in the vertical direction.

NUMBER OF DIRT LAYERS PER $10 \mathrm{~m}$

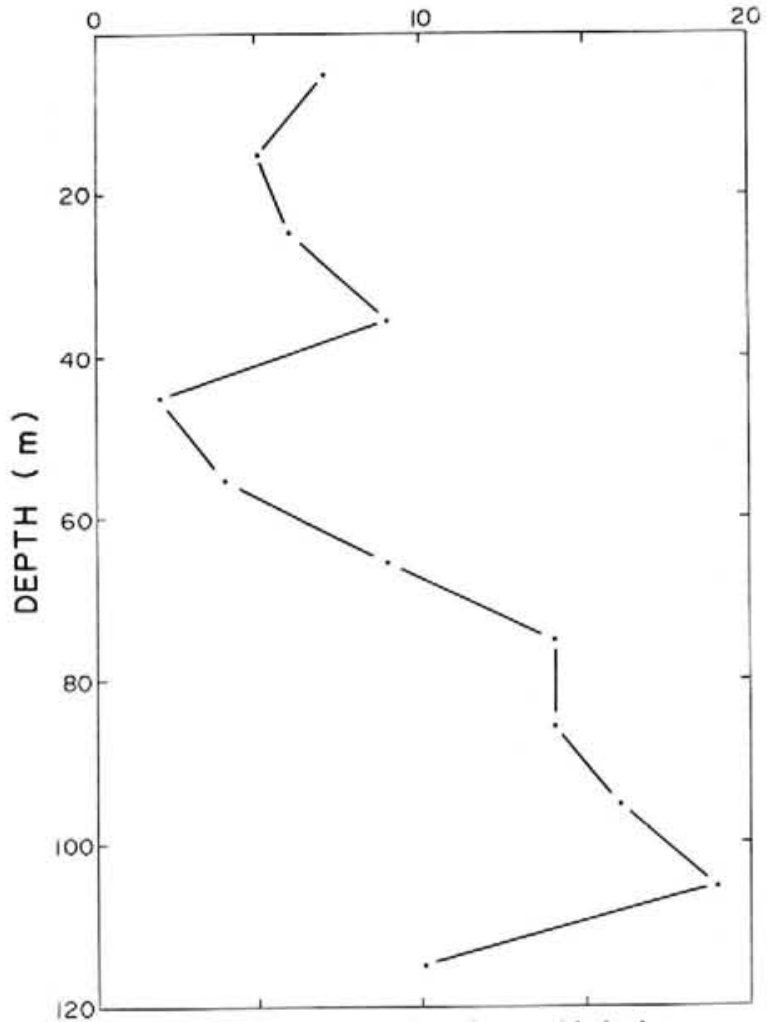

Fig. 5. Distribution of dirt layers with depth. 
If the ice cap has always been stagnant, it can never have been very much thicker than it is now. It is therefore unlikely to be a remnant of a Wisconsin ice sheet centered, for example. on either Ellesmere or Axel Heiberg Islands to the east.

\section{Crystal size and depth}

Firn- and ice-fabric studies above the firn line in Greenland (Langway, 1962) and Antarctica (Gow, I963) have shown that there is a gradual increase of crystal size with depth. In the Meighen Ice Cap core, an increase in crystal size from 0.5 to $4.0 \mathrm{~cm}^{2}$ occurs between the surface and $55 \mathrm{~m}$ (Fig. 3), but there is no further significant increase below this. For an explanation of the variation of crystal size with depth in this core one must consider the structure and process of formation of superimposed ice.

In a study of the formation of superimposed ice on the Devon Island Ice Cap, Koerner (unpublished) found that the crystal size of superimposed ice forming in summer is related, first, to the degree of saturation of the snow cover, and secondly, to the temperature of the ice under the snow. When the snow pack is mainly dry and the underlying ice is very cold, some melt water from the surface percolates down and refreezes rapidly on the ice to form finegrained superimposed ice. As the snow cover becomes increasingly saturated, melt water stands on the, by now, warmer ice and refreezes slowly to form much coarser ice. In cold summers, saturation of the snow proceeds slowly and mainly fine ice forms and some firn may be left at the end of summer. In warmer summers saturation of the snow cover is complete and water may stand on the surface to form very coarse ice when it refreezes. Dating of layers is not possible as two or more layers of different textures may form in one summer. However, the gross variations of crystal size with depth may be explained in terms of varying summer temperatures. Using this interpretation, the coarse ice between 55 and $115 \mathrm{~m}$ depth was deposited in warmer summers than the ice above or below it.

There are two objections to this interpretation. First, the extreme coarseness of many of the ice layers between 55 and $115 \mathrm{~m}$ depth cannot be simply related to relatively high summer temperatures. Ice of similar coarseness has not been found in any of a series of eight 5 -m cores from the superimposed-ice zone of the Devon Island Ice Cap, and it should form at altitudes just above the equilibrium line if the crystal size of superimposed ice is solely related to the summer temperature. Secondly, coarse ice layers were not found near the top of the core. During the transition from cold summers to the present condition of negative balance at the core site, there should have been a period when coarse ice accumulated if the crystal sizesummer temperature relationship is a close one. It is possible that such coarse ice layers have ablated during the present period of negative balance, in which case this objection no longer applies.

However, accumulation and ablation conditions on an ice cap may be altered by a change of surface slope without any climatic change. Gentle slopes on an ice cap are usually associated with poor drainage so that slush fields and ponds may develop during the summer melt period. Refreezing at the end of the melt season adds a layer of coarse ice to the surface as slush and ponded water refreeze relatively slowly. Conditions like these may have existed on the Meighen Ice Cap while it built up from a thickness of about to to $70 \mathrm{~m}$. By the time the ice cap was $70 \mathrm{~m}$ thick at the core site, a slope had developed to allow drainage of melt water and thereby prohibit the development of slush fields and ponds during the summer. During both conditions of steep and gentle slopes, fine ice will form early in the melt season at the base of the snow cover (Schytt, 1955). Whereas poor drainage retards ablation and often allows large thicknesses of coarse ice to form in relatively short summers, stecp slopes, by promoting more efficient drainage of melt water, accelerate ablation. In this case only the fine ice formed in early summer may remain at the end of the melt season.

A complete explanation of the change of crystal size with depth must include both the topographic and climatic arguments. 


\section{Relic ablation surface}

There is a significant hiatus in the distribution of dirt layers with depth in the $40-50 \mathrm{~m}$ interval (Fig. 5). This is at a similar level to the hiatus in the change of crystal size with depth (Fig. 3). It has already been suggested that the distribution of dirt layers in the core reflects variations of the area of ice-covered land. The hiatus may, therefore, represent a relic ablation surface formed after a period of negative balance when the ice cap not only thinned at the core site but also decreased in area.

The ablation surface is not marked by a very dirty layer as observations on the Devon Island Ice Cap by the author have shown that dirt accumulating at the surface during a period of negative balance may be washed off periodically in warm overcast weather. A decrease in both the area and thickness of the ice cap, before the uppermost $4^{\circ-} 5^{\circ} \mathrm{m}$ of ice accumulated, would account for the development of a slope at the core site, which is now only about $2 \mathrm{~km}$ from the ice-cap edge (Fig. I). It would also account for the sudden increase in the number of dirt layers above the $40^{-}-50 \mathrm{~m}$ depth interval as there was a greater area of ice-free land surrounding the ice cap once positive balance conditions restarted. Thus by the time the balance changed from negative to positive again at the core site, a slope had developed thereby altering the accumulation conditions so that superimposed ice, finer-grained than before, formed.

The relic ablation surface may be approximately dated if the previously determined maximum accumulation rate of $12.6 \mathrm{~cm}$ of ice/year is used. $40-50 \mathrm{~m}$ of ice now lie over the ablation surface and a further maximum of $13 \mathrm{~m}$ of ice have ablated in the present warm period. This much ice would have taken at least $400-500$ years to accumulate to which the period of negative balance now existing at the core site must be added. From the present depth of the deepest firn layer it has been postulated that a maximum of $13 \mathrm{~m}$ of ice have ablated from the surface. The mean specific balance at the core site between 1960 and 1966 was $-{ }_{15} \mathrm{~cm}$ of ice/year (Arnold, 1965 ; personal communication from W. S. B. Paterson). At this rate, negative-balance conditions have continued at the core site for at most 80 years. Paterson (unpublished), in a study of the temperature profile in the core hole, concluded that the mean annual surface temperature on the Meighen Ice Cap began increasing about 85 years ago, attained a maximum about 25 years ago, and has been decreasing since. This is in general agreement with the conclusion of the present study which makes the ablation surface at least $500-600$ years old.

On the northern Ellesmere Ice Shelf, Marshall (1955) found a disconformity at a depth of $25 \mathrm{~m}$, above which the ice consisted of granular iced firn. As Marshall (1955) estimated a lower accumulation rate there $(7.6 \mathrm{~cm}$ of ice/year) and probably more than $10 \mathrm{~m}$ of ice have ablated this century, the disconformity may be contemporaneous with the relic ablation surface on the Meighen Ice Cap. However, Crary's (1960) work on the same ice shelf and on the ice island T-3 gives a quite different time scale of positive and negative balance conditions. He concluded that the present period of negative balance has continued for the last approximately 400 years and was preceded by a period of positive balance about 1200 years long.

\section{Origin and age of the ice cap}

The $5 \mathrm{~m}$ of ice from the bottom of the core consist of relatively fine ice with a lower dirt content than the $40 \mathrm{~m}$ of ice above it (Figs. $2 \mathrm{a}$ and 5 ). Some of the layers in the bottom $5 \mathrm{~m}$ of ice may have developed from firn but other layers are composed of equidimensional crystals which are characteristic of superimposed ice. The fabric and the low dirt content suggest that for each of several years snow remained over most of Meighen Island and that the annual snow accumulation was largely changed to ice by melting and refreezing. Once a snow or ice cover remained throughout the year, the surface albedo in summer was so changed that even a return to slightly warmer conditions was insufficient to produce a negative balance. The occurrence of dirt layers throughout the entire core (Fig. 5) suggests that the ice cap has not covered the entire island for more than a few years at any time throughout its history. 
At a rate of growth of $12.6 \mathrm{~cm}$ of ice/year the ice cap would take approximately 1 ooo years to reach a maximum thickness of $125 \mathrm{~m}$. As it is almost certain that many years of negative balance occurred during its growth, the ice cap must be considerably older than this. However, as all the evidence indicates that it has never been very much thicker than at present it can hardly have survived the climatic optimum, which it almost certainly postdates. In this respect it forms a contrast with the ice sheets on Ellesmere Island (HattersleySmith, r961) and Axel Heiberg Island (Müller, 1966), and the Barnes Ice Cap (Ives, I962), which have survived from the Wisconsin glaciation. The Ellesmere Ice Shelf, like the Meighen Ice Cap, has developed in sub-Atlantic times (Crary, 1960).

\section{Summary}

I. The Meighen Ice Cap core shows a mean ice-crystal cross-sectional area of $0.6 \mathrm{~cm}^{2}$ but several coarse layers, consisting of crystals up to $20.0 \mathrm{~cm}^{2}$, occur. Stratification in the ice is often evident.

2. The ice-crystal and bubble fabric in the core shows no evidence of past or present ice movement.

3. The ice cap began its growth in sub-Atlantic times. A period of negative balance occurred during its growth and ended at least 500-600 years ago. This was followed by a period of positive balance. However, the specific balance at the core site has been negative for, at most, the past 80 years; a maximum of $13 \mathrm{~m}$ of ice has ablated during this time.

\section{Acknowledgements}

This study was conducted as part of the Polar Continental Shelf Project of the Canadian Department of Energy, Mines and Resources, under the direction of Dr E. F. Roots. The author is indebted for comments on a preliminary draft of the paper to Dr A. Stanley of the Department of Energy, Mines and Resources, Dr C. Langway of U.S. Army Cold Regions Research and Engineering Laboratory, and Dr G. Hattersley-Smith of the Defence Research Board of Canada. The study was envisaged, organized and assisted throughout by Dr W. S. B. Paterson of the Polar Continental Shelf Project, who also undertook the final presentation in the author's absence. The author would also like to thank Dr C. Bull of the Institute of Polar Studies, Ohio State University, for revising the manuscript.

\section{MS. received 15 March 1968}

\section{REFERENCES}

Arnold, K. C. 1965 . Aspects of the glaciology of Meighen Island, Northwest Territories. Canada. Fournal of Glaciology, Vol. 5. No. 40. p. 399-410.

Benson, C. S. 1962. Stratigraphic studies in the snow and firn of the Greenland ice sheet. U.S. Snow, Ice and Permafrost Research Establishment. Research Report 70.

Crary. A. P. 1960. Arctic ice island and ice shelf stulies. Arctic, Vol. 13. No. 1. p. 32-50.

Gow, A. J. 1963. Resulis of measurements in the 309 meter bore hole at Byrd station, Antarctica. Jounal of Glaciology, Vol. 4. No. 36, p. $771-84$.

Hattersley-Smith. G. 1961 . The ice cover of northern Ellesmere Island. Annals of the New York Academy of Sciences, Vol. 95 , No. 1, p. $282-89$.

Ives, J. D. 1962 . Indications of recent extensive glacierization in north-central Baffin Island, N.W.T. Journal of Glaciology, Vol. 4. No. 32, p. 197-205.

Koerner, R. M. Unpublished. A mass balance study: the Devon Island Ice Cap, Canada. [Ph.D. thesis, University of London, 1966.]

Langway, C. C., jr. 1962. Some physical and chemical investigations of a 411 meter deep Greenland ice core and their relationship to accumulation. Union Géodésique et Géophysique Internationale. Association Internationale d'Hydrologie Scientifique. Commission des. Neiges et Glaces. Colloque d'Obergurgl. 10-9-18-9 1962. p. 101-18. 
Marshall, E. W. 1955. Structural and stratigraphic studies of the northern Ellesmere Ice Shelf. Arctic, Vol. 8, No. 2 , p. $109^{-1} 4$.

Müller, F. 1966. Evidence of climatic fluctuations on Axel Heiberg Island, Canadian Arctic Archipelago. (In Fletcher, J. O., ed. Proceedings of the symposium on the Arctic heat budget and almospheric circulation, January 31 through February 4, 1966 , Lake Arrowhead, Califormia. Santa Monica, California, Rand Corporation, p. 13556.$)$

Paterson, W. S. B. Unpublished. A temperature profile through the Meighen Ice Cap. Arctic Canada. [Paper presented at International Union of Geodesy and Geophysics, general assembly, Berne, 1967.1

Schytt, V. 1955. Glaciological investigations in the Thule Ramp area. U.S. Snow, Ice and Permafrost Research Establishment. Report 28.

Schytt, V. 1958. Glaciology. II. Snow studies at Maudheim.- Snow studies inland.-The inner structure of the ice shelf at Maudheim as shown by core drilling. Norwegian-British-Swedish Antarctic Expedition, 1949-52. Scientific Results (Oslo, Norsk Polarinstitutt), Vol. 4, A-C. 